\title{
Judicial Dialogue in Social Media Cases in Europe: Exploring the Role of Peers in Judicial Adjudication
}

\author{
Evangelia Psychogiopoulou \\ Hellenic Foundation for European \& Foreign Policy, Athens, Greece \\ Corresponding author: epsychogiopoulou@eliamep.gr
}

(Received 10 August 2020; accepted 09 November 2020)

\begin{abstract}
This Article aims to examine the social media jurisprudence of national courts in a selected set of EU Member States by focusing on judicial dialogue specifically via references to the case law of other courts. Do judges in social media cases engage with the case law of peers, and if so how and to what extent? The analysis investigates whether national judges draw on the jurisprudence of higher domestic courts, foreign courts and/or European supranational courts- the Court of Justice of the European Union (CJEU) and the European Court of Human Rights (ECtHR) - and explores the use of such jurisprudence. It is based on 147 cases from the constitutional and/or supreme courts of Bulgaria, Croatia, Greece, Italy, Latvia, Slovakia, and Slovenia. Although judicial dialogue is generally limited in the cases under study, the analysis illustrates the different ways in which courts interact with the rulings of peers and informs on the latter's contribution to judicial assessment.
\end{abstract}

Keywords: Judicial dialogue; social media; national courts; CJEU; ECtHR

\section{A. Introduction}

Digitization has transformed society on several fronts. In recent years, we have seen the rise of social networks, the expansion of blogging and micro-blogging, the development of collaborative knowledge and video-sharing sites, and the broad uptake of instant messaging and online forums. The digital revolution has multiplied communication channels, increasing the number of spaces available for deliberation and debate. Social networks, blogs, chat rooms, and so on have expanded the possibilities of individuals to exercise the right to freedom of expression, and to obtain and diffuse information. ${ }^{1}$ Digitization has brought to the fore new tools for expression, revolutionizing access to information and knowledge.

Dr. Evangelia Psychogiopoulou is a senior research fellow at the Hellenic Foundation for European and Foreign Policy (ELIAMEP) and legal counsellor for the Greek Ministry of Culture and Sports. Her research focuses on EU law and governance, fundamental rights, judicial dialogue, (digital) media law and policy, and the regulation of culture. She has led research for the EU institutions and she has participated in several collaborative research projects funded by the EU. She studied law at the National and Kapodistrian University of Athens. She holds a DEA in EU Law from Paris I University and a doctorate in law from the European University Institute.

${ }^{1}$ Frank La Rue, Report of the Special Rapporteur on the Promotion and Protection of the Right to Freedom of Opinion and Expression, United Nations General Assembly (May 16, 2011), https://www2.ohchr.org/english/bodies/hrcouncil/ docs/17session/A.HRC.17.27_en.pdf; COUNCIL of THE EuropeAn Union, EU Human Rights GUIDELINES ON FrEEDOM OF EXPRESSION ONLINE AND OFFLINE (2014), https://www.consilium.europa.eu/uedocs/cms_data/docs/pressdata/EN/foraff/ 142549.pdf.

(c) The Author(s) 2021. Published by Cambridge University Press on behalf of the German Law Journal. This is an Open Access article, distributed under the terms of the Creative Commons Attribution licence (http://creativecommons.org/licenses/by/4.0/), which permits unrestricted re-use, distribution, and reproduction in any medium, provided the original work is properly cited. 
Digitization has also yielded a number of challenges for policy-makers. Social media has facilitated the dissemination of illegal content, ${ }^{2}$ exposed children and other vulnerable groups to harmful content, ${ }^{3}$ bred disinformation, ${ }^{4}$ and undermined democratic values. Tension between freedom of expression and other rights and freedoms - such as the right to privacy, data protection, human dignity, and intellectual property, amongst others-have also come into greater prominence online. ${ }^{5}$ The challenges and opportunities digitization has raised for public policy have sparked heated debate over regulatory standards in Europe ${ }^{6}$ with few regulatory initiatives having been put into practice so far. ${ }^{7}$ Less consideration has been given,

\footnotetext{
${ }^{2}$ Such as incitement to terrorism, incitement to violence or hatred directed at groups or individuals on the basis of characteristics such as race, color, religion, descent, and national or ethnic origin, and child sexual abuse material.

${ }^{3}$ This is content that is not illegal per se, but considered to be unsuitable or inappropriate for particular groups of individuals, and thus has a harmful influence. See Council of Europe, Recommendation CM/Rec (2012)4 of the Committee of Ministers to member states on the protection of human rights with regard to social networking services (Adopted by the Committee of Ministers on April 4, 2012 at the 1139th meeting of the Ministers' Deputies), paras. 5-11.

${ }^{4}$ Claire Wardle and Hossein Derakhshan, Information Disorder: Toward an Interdisciplinary Framework for Research
} and Policy Making, Council of Europe (Sept. 27, 2017), https://rm.coe.int/information-disorder-report-november-2017/ 1680764666.

${ }^{5}$ See Comm. of Ministers, Recommendation CM/Rec (2012)4, para. 3.

${ }^{6} \mathrm{See}$, e.g., Communication from the Commission to the European Parliament, the Council, the European Economic and Social Committee and the Committee of the Regions, Tackling Illegal Content Online, Towards an Enhanced Responsibility of Online Platforms, COM (2017) 555 (Sept. 28, 2017); French Republic, 'Creating a French Framework to Make Social Media Platforms More Accountable: Acting in France with a European Vision, Mission Report, "Regulation of Social Networks Facebook Experiment”, May 2019, https://www.numerique.gouv.fr/uploads/Regulation-of-social-networks_Mission-report_ ENG.pdf; Secretary of State for Digital, Culture, Media \& Sport and Secretary of State for the Home Department, 'Online Harms White Paper', Apr. 2019, https://assets.publishing.service.gov.uk/government/uploads/system/uploads/attachment_ data/file/793360/Online_Harms_White_Paper.pdf; Damian Tambini, The Differentiated Duty of Care: A Response to the Online Harms White Paper, 11(1) J. MEDIA L. 28 (2019). On digital media and platform governance more broadly, see Philip M. Napoli, Social Media and the Public Interest: Governance of News Platforms in the Realm of Individual and Algorithmic Gatekeepers, 39 Telecomm. Pol'y 751 (2015); Philip Napoli and Robyn Caplan, Why Media Companies Insist They're Not Media Companies, Why They're Wrong, and Why It Matters, 22(5) FIRST MondAY (2017), https:// firstmonday.org/ojs/index.php/fm/article/view/7051/6124; Tarleton Gillespie, Governance of and by Platforms, in THE Sage Handbook of Social Media 254 (Jean Burgess, Alice Marwick \& Thomas Poell eds., 2018); Robert Gorwa, What is Platform Governance?, 22(6) INFO., CoMMC'N \& SoC'Y 854 (2019); Terry Flew, Fiona Martin \& Nicolas Suzor, Internet Regulation as Media Policy: Rethinking the Question of Digital Communication Platform Governance, 10(1) J. DiGIT. MEdia \& POL'y 33 (2019).

${ }^{7}$ In particular, see the so-called Avia Law adopted by the National Assembly in France on May 13, 2020 (Law 2020-766, https://www.legifrance.gouv.fr/eli/loi/2020/6/24/JUSX1913052L/jo/texte), many provisions of which were declared unconstitutional by the French Constitutional Court. See Const. Council, Decision 2020-801 DC of June 18, 2020, https://www.conseil-constitutionnel.fr/decision/2020/2020801DC.htm. See also Germany's Network Enforcement Act (the NetzDG Law) (Jan. 1, 2018), https://www.bmjv.de/SharedDocs/Gesetzgebungsverfahren/Dokumente/NetzDG_ engl.pdf?__blob=publicationFile\&v=2); William Echikson \& Olivia Knodt, Germany's NetzDG: A Key Test for Combatting Online Hate, Research Report No. 2018/09 CEPS (Nov. 2018); Kirsten Gollatz, Martin J. Riedl \& Jens Pohlmann, Removals of Online Hate Speech in Numbers (Aug. 9, 2018), https://www.hiig.de/en/removals-of-onlinehate-speech-numbers/; Wolfgang Schulz, Regulating Intermediaries to Protect Privacy Online: The Case of the German NetzDG, HIIG Discussion Paper Series 1/2018, https://www.hiig.de/wp-content/uploads/2018/07/SSRNid3216572.pdf. In an EU context, see in particular Commission Recommendation C(2018) 1177 of Mar. 1, 2018 on Measures to Effectively Tackle Illegal Content Online; Directive 2017/541/EU of the European Parliament and of the Council of 15 March 2017 on Combating Terrorism and Replacing Council Framework Decision 2002/475/JHA and Amending Council Decision 2005/671/JHA, 2017 O.J. (L 88) 6; Directive 2018/1808/EU of the European Parliament and of the Council of 14 November 2018 Amending Directive 2010/13/EU on the Coordination of Certain Provisions Laid Down by Law, Regulation or Administrative Action in Member States Concerning the Provision of Audiovisual Media Services (Audiovisual Media Services Directive) in View of Changing Market Realities, 2018 O.J. (L 303) 69 (containing rules on video-sharing platform services at Arts. 28a and 28b); Lubos Kuklis, Media Regulation at a Distance: Video-Sharing Platforms in AVMS Directive and the Future of Content Regulation, 2(2020) Media Laws, Rivista di Diritto Dei Media 95 (2020); Directive 2019/790/EU of the European Parliament and of the Council of 17 April 2019 on Copyright and Related Rights in the Digital Single Market and Amending 
however, to the role of courts in this evolving legal area, despite the fact that both national and supranational courts in Europe have been increasingly required to rule on digital and social media disputes.

This Article seeks to untangle the social media jurisprudence of national courts in a selected set of EU Member States. It identifies and analyzes relevant case law, exploring the interpretative steps of the deciding judges. In doing so, the Article focuses on judicial dialogue and sheds light on the nature and breadth of judicial interaction via references to and use of the jurisprudence of peers. In social media cases, judges may be particularly inclined to look towards the rulings of other courts to cope with complex legal questions in the new environment. Do national judges engage with the jurisprudence of higher domestic courts, foreign courts and European supranational courtsnamely the CJEU and the ECtHR - when deciding social media disputes? What is the volume of judicial interaction in social media cases and what is the contribution of judicial dialogue to solving the dispute at hand?

To answer these questions, the Article is structured as follows. Section B expands on the concept of judicial dialogue that is employed in this study and discusses its relevance and importance for judicial decision-making. Section $C$ provides an overview of the court rulings reviewed and general patterns of judicial dialogue identified. Sections D and E explore the input of judicial dialogue to judicial reasoning in constitutional and supreme court cases respectively from Bulgaria, Croatia, Greece, Italy, Latvia, Slovakia, and Slovenia. The emphasis on higher courts allows for a better understanding of the input of judicial dialogue in social media rulings with final legal authority and constitutional implications. Supreme courts are commonly required to judge questions of law with final jurisdiction. Constitutional courts tend to be entrusted with duties such as protecting the fundamental rights of individuals set forth in domestic constitutions, keeping the legislature in check and resolving institutional disputes between different organs or levels of state. Supreme and constitutional courts may be particularly likely to use judicial dialogue to ensure that their reasoning is well-informed and properly substantiated given the authoritative nature of their rulings and the broad influence that these rulings exert. Country selection combines the study of western European democracies with the study of states from central and eastern Europe, where courts-especially higher courts-have established themselves as important players in the transition towards liberal democracy. It also reflects the variety of EU Member States in terms of legal systems and judicial structures. It is worth noting, for instance, that not all the countries under examination rely on a constitutional court to uphold constitutional provisions. ${ }^{8}$ The list of countries chosen further represents different levels of experience with the EU legal order on the one hand and the European Convention on Human Rights (ECHR) on the other, which may have a role to play regarding judicial interaction with the CJEU and the ECtHR. ${ }^{9}$

\footnotetext{
Directives 96/9/EC and 2001/29/EC, 2019 O.J. (L 130) 92 (containing rules for online content-sharing providers at Art. 17); Christina Angelopoulos \& Jão Pedro Quintais, Fixing Copyright Reform, 10(2019) JIPITEC 147 (2019); European Commission's proposal for a Regulation of the European Parliament and of the Council on Preventing the Dissemination of Terrorist Content Online, $\operatorname{COM}(2018)$ 640. See also Directive 2011/93/EU of the European Parliament and of the Council of 13 December 2011 on Combating the Sexual Abuse and Sexual Exploitation of Children and Child Pornography, and Replacing Council Framework Decision 2004/68/JHA, 2011 O.J. (L 335) 1; Directive 2000/31/EC of the European Parliament and of the Council of 8 June 2000 on Certain Legal Aspects of Information Society Services, in Particular Electronic Commerce, in the Internal Market, (2000) O.J. (L 178) 1 (providing Internet intermediaries with significant protections in the form of a liability exemption under certain conditions, Arts. 12-14, and the prohibition of a general obligation of monitoring, Art. 15).

${ }^{8}$ In Greece, there is no constitutional court as such. All domestic courts are bound to refrain from applying legislation whose content is contrary to the Constitution. This entails a shared control of constitutionality.

${ }^{9}$ Italy was a founding member of the original European Communities, and Greece joined the European integration process in the early 1980s, whereas the other countries under examination became EU members later in the 2000s. Similarly, the ECHR's entry into force in Italy occurred in 1955, in Greece in 1974, and in the central and eastern European countries under study in the 1990s.
} 


\section{B. Judicial Dialogue}

Judicial dialogue is generally understood to denote engagement with the case law of other courts. ${ }^{10}$ In her seminal work, 'A Global Community of Courts,' Anne-Marie Slaughter describes the growing interaction between courts worldwide as being forged by judges' 'common function of resolving disputes under rules of law', relying above all on judges' self-awareness. ${ }^{11}$ Judges, Slaughter argues, see each other as fellow professionals in an endeavor that cuts across national boundaries: Facing common problems and based on a sense of participation in 'a common judicial enterprise', ${ }^{12}$ they may seek to learn from one another's experience and cooperate to resolve disputes. Two main strands of dialogue were identified in light of such considerations: Constitutional crossfertilization through constitutional courts' citation of the jurisprudence of foreign constitutional courts; and cooperation between national courts in transnational litigation concerning cross-border disputes.

Other authors have claimed that judicial dialogue is an inappropriate term, both conceptually and empirically, for much of the interaction that takes place between judges, ${ }^{13}$ through face-toface meetings, judicial conferences, and formal and informal judicial networks, aimed at connecting judges and encouraging the exchange of ideas and experience. A distinction should also be drawn between judicial dialogue understood as judicial cooperation in the form of non-binding engagement with other courts' rulings and judicial dialogue that goes beyond voluntary inspiration. ${ }^{14}$ To illustrate, pursuant to Article 267 of the Treaty on the Functioning of the European

\footnotetext{
${ }^{10}$ On judicial dialogue see Laurence R. Helfer \& Anne-Marie Slaughter, Toward a Theory of Effective Supranational Adjudication, 107(2) Yale L.J. 273 (1997); Christopher McCrudden, Common Law of Human Rights?: Transnational Judicial Conversations on Constitutional Rights, 20(4) OxFord J. LEGAL STUD. 499 (2000); Francis Jacobs, Judicial Dialogue and the Cross-Fertilization of Legal Systems: The European Court of Justice, 38(3) TEx. INT'L L.J. 547 (2003); Allan Rosas, The European Court of Justice in Context: Forms and Patterns of Judicial Dialogue, 1(2) EUR. J. LEGAL STUd. 1 (2007); Allan Rosas, Methods of Interpretation: Judicial Dialogue, in The Role of InTERnAtional CourTs 187 (Carl Baudenbacher \& Erhard Busek eds., German Law Publishers 2008); Marta Cartabia, Europe and Rights: Taking Dialogue Seriously, 5(1) Eur. Const. L. Rev. 5 (2009); Sir Basil Markesinis \& Jörg Fedtke, Engaging WITH ForEIGN LAW (Hart Publishing 2009); Ricardo Lorenzetti, Global Governance: Dialogue Between Courts, EUI RSCAS PP, 2010/03, Global Governance Programme, European, Transnational and Global Governance, https://cadmus.eui.eu/handle/1814/ 15235; Vicki C. Jackson, Constitutional Engagement in a Transnational Era (Oxford University Press 2010); Takis Tridimas, Constitutional Review of Member State Action: The Virtues and Vices of an Incomplete Jurisdiction, 9 INT'L J. Const. L. 737 (2011); Anthony Arnull, Judicial Dialogue in the European Union, in Philosophical Foundations OF European Union LaW 109 (Julie Dickson \& Pavlos Eleftheriadis eds., Oxford University Press 2012); Michal Bobek, Comparative Reasoning in European Supreme Courts (Oxford University Press, 2013); Gráinne de Búrca, After the EU Charter of Fundamental Rights: The Court of Justice as a Human Rights Adjudicator?, 20(2) MAASTRICHT J. EuR. \& Compar. L. 168 (2013); Elaine Mak, Judicial Decision-Making in a Globalized World: A Comparative Analysis of the Changing Practices of Western Highest Courts (Hart Publishing 2013); Maartje de Visser \& Monica Claes, Courts United?: On European Judicial Networks, in LAwYering Europe: European LAW as a TransNATIONAL SOCIAL FiELD (Antoine Vauchez \& Bruno de Witte eds., Hart Publishing 2013); Eva Kassoti, Fragmentation and Inter-Judicial Dialogue: The CJEU and the ICJ at the Interface, 8(2) EUR. J. Legal STUD. 21 (2015); Monica Claes, The Validity and Primacy of EU Law and the "Cooperative Relationship" Between National Constitutional Courts and the Court of Justice of the European Union, 23(1) MaAstricht J. Eur. \& COMPar. L. 151 (2016); Antonios Tzanakopoulos, Judicial Dialogue as a Means of Interpretation, in The INTERPRETATION OF INTERNATIONAL LAW By DOMESTIC COURTS: Uniformity, Diversity, Convergence (Helmut Philipp Aust \& Georg Nolte eds., Oxford University Press 2016); Bruno de Witte, The Preliminary Ruling Dialogue: Three Types of Questions Posed by National Courts, in NATIONAL CourTs and EU Law: New Issues, Theories and Methods 15 (Bruno de Witte, Juan A. Mayoral, Urszula Jaremba, Marlene Wind \& Karolina Podstawa eds., 2016); Hege Elisabeth Kjos, Judicial Dialogue and Human Rights (Amrei Müller ed., Cambridge University Press 2017); Madalina Moraru, Galina Cornelisse \& Philippe De Bruycker, LAW AND JUDICIAL Dialogue on the Return of Irregular Migrants from the European Union (Hart Publishing 2020).

${ }^{11}$ Anne-Marie Slaughter, A Global Community of Courts, 44 Harv. INT'L L.J. 191, 192 (2003).

${ }^{12} I d$. at 193.

${ }^{13}$ Tom Gerald Daly, Baby Steps Away from the State: Regional Judicial Interaction as a Gauge of Post-National Order in South America and Europe, 3 CAmbridge J. InT'L \& Compar. L. 1011 (2014).

${ }^{14}$ Krystyna Kowalik-Bańczyk \& Oreste Pollicino, Migration of European Judicial Ideas Concerning Jurisdiction over Google on Withdrawal of Information, 17 GERMAN L.J. 315 (2016).
} 
Union, any court or tribunal in the EU Member States may-while a final court must-refer a question on the interpretation of EU law or on the validity of EU legislation that is raised in a case pending before it, for a preliminary ruling to the CJEU. The CJEU's ruling is binding on the referring court and all courts in the EU Member States for that matter. ${ }^{15}$ The preliminary ruling procedure, a 'formal mechanism' of judicial dialogue between the CJEU and the referring court, ${ }^{16}$ differs substantially from instances of judicial dialogue in which national courts voluntarily draw on the decisions of other courts - whether supranational, national or foreign. Voluntary reference to other courts' rulings may serve as persuasive authority, corroborating the reasoning of the deciding judge. It may also allow the deciding court to juxtapose its reasoning to the reasoning of others and sometimes to even criticize judicial stances and approaches to similar legal issues elsewhere.

It becomes evident then that judicial dialogue can take many forms: It incorporates references and citations to other courts' judgments, mutual cooperation in transnational disputes, mandatory cooperation, and judges' networking and meetings in person. Although this study acknowledges that judicial dialogue is multi-faceted and can occur in different contexts, it approaches judicial dialogue through case law references. Two main strands of judicial dialogue receive attention in this context: horizontal and vertical judicial dialogue, depending on whether the interacting courts operate at the same level. More specifically, three distinct types of judicial dialogue are examined: Internal horizontal judicial dialogue, external horizontal judicial dialogue, and external vertical judicial dialogue. Internal horizontal judicial dialogue refers to the interaction between higher courts within the same EU Member State, for example a supreme court interacts with another supreme court or the constitutional court in the same EU Member State. External horizontal judicial dialogue refers to the interaction between higher courts operating at the same level in different EU Member States or in an EU Member State and a non-EU country, for example a supreme court in country A interacts with a supreme court or the constitutional court in country B. External vertical judicial dialogue is understood as the interaction between a national higher court and European supranational courts- the CJEU and the ECtHR. Case law references are given consideration only when the cases referred to are relevant for the-social- media dimension of the dispute in question. Judicial dialogue on any other matter does not come within the scope of the study.

The analysis is based on the premise that courts may have good reasons to look for insight and inspiration in the rulings of peers. To begin with, judicial dialogue can facilitate finding answers to complex but common legal problems. ${ }^{17}$ By contrasting self-referential judgments that may undermine a judge's understanding of what solution works best in a given dispute, judicial interaction that induces judges to consider how colleagues have dealt with similar questions elsewhere can help courts learn from their accumulated experience. Judicial dialogue can also improve the quality of the judicial output. Recourse to 'comparative' jurisprudence can contribute to betterinformed and properly reasoned judgments, enhancing clarity and comprehensiveness in argumentation. Ultimately, an informed ruling with elaborate reasoning can gain legitimacy. ${ }^{18} \mathrm{~A}$ court decision that considers the ways similar problems and claims have been tackled by fellow judges makes clear to the litigants_-and wider society_-that the deciding judge has made the effort to carefully engage with the relevant arguments. Simply put, it shows that the decision was reached after all potential sources of input were given attention. No less important, judicial dialogue may

\footnotetext{
${ }^{15}$ On the development of precedent, see Case 28 to 30/62, Da Costa en Schaake NV and Others v. Administratie der Belastingen (Mar. 17, 1963), https://curia.europa.eu/juris/liste.jsf?num=C-28/62; Case 283/81, CILFIT v. Ministero della Sanità (Oct. 6, 1982), https://curia.europe.eu/juris/liste.jsf?num=C-283/81; C-453/00, Kühne \& Heitz (Jan. 13, 2004), http://curia.europa.eu/juris/liste.jsf?num=C-453/00.

${ }^{16}$ Claes, supra note 10 .

${ }^{17}$ Helfer \& Slaughter, supra note 10, at 326; Hege Elisabeth Kjos, Judicial Dialogue and Human Rights 4 (Amrei Müller ed., 2017); Markesinis \& Fedtke, supra note 10, at 372.

${ }^{18}$ See de Búrca, supra note 10 , at 180 .
} 
shield the national judge from political or other pressures ${ }^{19}$ and bolster judicial authority-especially in politically, socially, or otherwise controversial cases. ${ }^{20}$

The benefits that judicial dialogue may bring do not necessarily come at the expense of judicial autonomy: Judges enjoy a considerable amount of discretion regarding the sources they take into account and the arguments they formulate unless "cooperation" is required. ${ }^{21}$ Concerning the use of foreign case law, in particular-as has been usefully explained in the literature-the starting point for the national judge will always be the domestic set of rules, on which the eventual argument justifying the decision taken will need to be grounded. ${ }^{22}$ If the reasoning is not convincing in domestic law, foreign case law will not be able to help. If the reasoning is convincing in domestic law, foreign case law can support and lend weight to the national legal argument. Because of the myriad differences in national legal orders, no simple borrowing of foreign argumentation will ever be easy or straightforward. ${ }^{23}$ Some form of adjustment will always be necessary in order to integrate foreign courts' argumentation in domestic judicial reasoning and fit the case and legal context at hand.

Judicial decision-making in liberal-democratic systems, especially at the level of higher courts, is shaped by a multiplicity of legal, procedural, institutional, organizational and personal factors ${ }^{24}$ that have a bearing on the way judges approach the rulings of peers. Domestic law, established practice, judicial culture as well as the education and experiences of individual judges can promote or conversely hinder judicial interaction. Still, in social media cases, judges may be particularly inclined to engage with the rulings of other courts - national, foreign, and supranational. This is not only due to the pace of technology's evolution that may put the judiciary under strain. It is also related to the fact that social media and platform-specific regulation has thus far been rather limited overall. Judicial dialogue may be particularly useful in a field of law that is still developing. A judicial search for inspiration could pave the way for developing legal protection at the national level. By steering attention to solutions found elsewhere, judicial dialogue could underline insufficiencies in domestic law and policy, thus helping advance domestic legal standards. Moreover, in Europe's post-national legal order, where supranational and national legal systems co-exist, judicial dialogue between national and supranational courts can prove particularly helpful in cases where the applicable rules originate in supranational forums.

Other factors that may support judicial dialogue in social media cases relate to the fundamental rights dimension that is inherent in social media cases, especially from the perspective of free speech and its interaction with other rights and interests, although evidently, not all social media cases are framed as fundamental rights cases. The argument made is that judicial dialogue can lead to better-informed and properly reasoned judgments on key issues pertaining to fundamental rights. Human rights are regulated in Europe by national and supranational regimes, such as the EU and the Council of Europe. Although relevant regimes do not operate in isolation from each other, they naturally come with their own features and characteristics. Judicial interaction between courts in Europe can mitigate the risk of conflicting interpretations, sharpened by the novelty of the factual and legal context that new technologies create. This consistency argument is essentially an argument of fairness: It is important to treat like cases alike, ${ }^{25}$ particularly on issues concerning fundamental rights which are associated with the dignity of the human person

\footnotetext{
${ }^{19}$ Helfer \& Slaughter, supra note 10 , at 371.

${ }^{20}$ Kjos, supra note 17 , at 513 .

${ }^{21}$ See, e.g., supra Part B (discussing the preliminary reference procedure).

${ }^{22}$ John Bell, The Argumentative Status of Foreign Legal Arguments, 8 Utrecht L. Rev. 8 (2012).

${ }^{23}$ Antoine Hol, Highest Courts and Transnational Interaction: Introductory and Concluding Remarks, 8 Utrecht L. Rev. 1, 7 (2012).

${ }^{24}$ Elaine Mak, Reference to Foreign Law in the Supreme Courts of Britain and the Netherlands: Explaining the Development of Judicial Practices, 8 Utrecht L. Rev. 20 (2012).

${ }^{25}$ See Jeremy WALdron, Treating Like Cases Alike in the World: The Theoretical Basis of the Demand for Legal Unity, in Highest Courts and Globalization 99 (Sam Muller and Sidney Richards eds., Hague Academic Press 2010).
} 
and the promotion of human well-being. Judicial dialogue can limit disjointed and insufficiently informed case law on a growing variety of fundamental rights issues, promoting adjudicative coherence in social media disputes.

\section{Judges in Dialogue}

Our sample of social media rulings contains 147 cases from constitutional and supreme courts in the EU Member States reviewed from between January 1, 2012-May 31, 2018. The selection covers cases on social media as well as cases on blogs and online forums, which share similar characteristics with social media, in particular connective communication-namely communication that is mostly driven by the need to connect and relate to others-creative self-expression through usergenerated content and interactivity. ${ }^{26}$ Cases on traditional news media that operate on the Internet and news portals have been incorporated in the study when they specifically deal with activities that display similar features to social media-for example, cases concerning user-generated content in the form of online readers' comments on published articles. Cases concerning peer-to-peer file-sharing networks which do not share all the above mentioned characteristics are covered only when they raise broader issues of importance to social media from a fundamental rights perspective.

Most of the higher court cases under examination make no reference to the case law of other national higher courts, foreign courts, the CJEU or the ECtHR. Judicial dialogue in the social media cases reviewed is rather limited. Only in ten cases within our sample, seven percent, did national judges refer to other courts' rulings. Three out of the five constitutional court cases identified and seven out the 142 supreme court cases studied engaged in judicial dialogue.

Interestingly, the constitutional and supreme court rulings that engaged in judicial dialogue also engaged in fundamental rights reasoning. This indicates that cases that address fundamental rights might enjoy more opportunities for judicial interaction. In such cases, courts may usefully draw on domestic higher court rulings, interpreting for instance the rights and freedoms enshrined in the constitution. In response to parties' pleadings but also of their own accord, courts may also examine whether any supranational sources of fundamental rights protection, such as the Charter of Fundamental Rights (CFR) of the EU or the European Convention on Human Rights (ECHR), apply in cases with a fundamental rights dimension. If so, the national judge will naturally need to define the scope and level of protection afforded to fundamental rights by the relevant supranational sources. Resort to the jurisprudence of the latter's interpretative organs could prove particularly helpful in this regard.

Sections D and E below explore the contribution of judicial dialogue to judicial reasoning on social media in constitutional and supreme court cases respectively. Evidently, reference to other courts' rulings depends on the factual circumstances of a case and whether or not any similar cases have been assessed in other judicial fora. Other important factors that can nurture or conversely stifle judicial dialogue may have to do with the domestic legal framework and judicial culture, judges' level of awareness and knowledge of foreign and European case law in the field of interest, the arguments of the parties, the degree of similarities and differences between legal systemsparticularly regarding engagement with foreign case law-and the applicability of EU law in the dispute that is pending before the national court which can trigger attention to CJEU decisions. Although judicial dialogue is generally limited in the cases under study, the analysis attests to the different ways in which courts engage with the rulings of other courts and informs on the nature of the latter's contribution to judicial evaluation.

\footnotetext{
${ }^{26}$ See Natalie Fenton, The Internet and Social Networking, in Misunderstanding the Internet 123 (James Curran, Natalie Fenton and Des Freedman, Misunderstanding the Internet, Routledge 2012).
} 


\section{Constitutional Courts: Judicial interaction with the ECtHR and Foreign Courts}

All three constitutional court cases within our sample that engaged in judicial dialogue made reference to the case law of the ECtHR. ${ }^{27}$ Two of these cases also engaged in external horizontal judicial dialogue. ${ }^{28}$ Reference to ECtHR case law and foreign court rulings mostly served to support the reasoning of the deciding judge. In some instances, though, it merely took place as part of the legal background and context of the case.

Decision 313/2013 of December 17, 2013 by the Italian Constitutional Court belongs to the group of cases where reference to the ECtHR's jurisprudence was made as a supporting argument. ${ }^{29}$ The case stemmed from the posting on a blog of allegedly defamatory statements by a member of the Italian Senate against the President of the Italian Republic. The Italian Constitutional Court referred to the ECtHR rulings in Cordova v. Italy ${ }^{30}$ and CGIL and Cofferati v. Italy ${ }^{31}$ to reinforce its reasoning that parliamentary immunity should only be granted for statements made in connection with the exercise of parliamentarian functions. Pursuant to Article 68(1) of the Italian Constitution, members of parliament should not be held accountable for any opinions expressed or votes cast "in the performance of their function." 32 With reference to the above mentioned ECtHR rulings, the Constitutional Court observed that the right of individuals to have access to a court would be restricted in a manner incompatible with Article 6(1) ECHR on the right to a fair trial if parliamentarians could escape liability for any statement that "might be political in nature or connected with political activities." 33

In Cordova v. Italy, the ECtHR had recognized that there was a long-standing practice for states party to the ECHR to confer varying degrees of immunity to parliamentarians, with the aim of securing free speech and preventing partisan complaints from interfering with parliamentary functions, ${ }^{34}$ in view of the role of parliament as an essential forum for political debate. ${ }^{35}$ Parliamentary immunity should not in principle be regarded as imposing a disproportionate restriction on the right of access to a court. ${ }^{36}$ However, it "would not be consistent with the rule of law in a democratic society, or with ... Article 6(1) [ECHR] ... if a State could, without restraint or control by the Convention enforcement bodies, remove from the jurisdiction of the courts a whole range of ... claims." ${ }^{37}$ Parliamentary speech that was not connected with the exercise of parliamentary functions should not come within the ambit of protection offered specifically for opinions expressed in the exercise of parliamentary duties. ${ }^{38}$ On the basis of such considerations-replicated for the most part in CGIL and Cofferati v. Italy - the Italian Constitutional Court concluded that enjoyment of parliamentary immunity required rigorous scrutiny of a "functional link" between the parliamentarian's opinion and the exercise of parliamentary functions. ${ }^{39}$

\footnotetext{
${ }^{27}$ Corte costituzionale (Corte cost.) [Constitutional Court], Case 313/2013, 17 dicembre 2013, http://www.giurcost.org/ decisioni/2013/0313s-13.html (It.); Ústavného súdu Slovenskej republiky [Constitutional Court of the Slovak Republic], Case II. ÚS 307/2014-45, Dec. 18, 2014, https://tinyurl.com/y8yot6zd; Ustavno sodišče Republike Slovenije [Constitutional Court of the Republic of Slovenia], Case Up-540/11, ECLI:SI:USRS:2014:Up.540.11, Feb. 13, 2014, https://www.us-rs.si/ decisions/?lang=en\&id=111578.

${ }^{28}$ Ústavného súdu Slovenskej republiky [Constitutional Court of the Slovak Republic], Case II. ÚS 307/2014-45, Dec. 18, 2014, https://tinyurl.com/y8yot6zd; Ustavno sodišče Republike Slovenije [Constitutional Court of the Republic of Slovenia], Case Up-540/11, ECLI:SI:USRS:2014:Up.540.11, Feb. 13, 2014, https://www.us-rs.si/decisions/?lang=en\&id=111578.

${ }^{29}$ Corte costituzionale (Corte cost.) [Constitutional Court], Case 313/2013, 17 dicembre 2013, http://www.giurcost.org/ decisioni/2013/0313s-13.html (It.).

${ }^{30}$ Cordova v. Italy, App. No. 40877/98 (Jan. 30, 2003), http://hudoc.echr.coe.int/eng?i=001-60913.

${ }^{31}$ CGIL and Cofferati v. Italy, App. No. 46967/07 (Feb. 24, 2009), http://hudoc.echr.coe.int/eng?i=001-91508.

${ }^{32}$ Art. 68(1) Costituzione (Cost.) [Constitution] (It.).

${ }^{33}$ See Corte costituzionale, Case $313 / 2013$ at para. 5 .

${ }^{34}$ Cordova, App. No. $40877 / 98$ at para. 55.

${ }^{35}$ Id. at para. 59 .

${ }^{36} \mathrm{Id}$. at para. 60 .

${ }^{37} I d$. at para. 58.

${ }^{38} I$ d. at para. 62.

${ }^{39}$ Corte costituzionale, Case $313 / 2013$ at para. 6 .
} 
Decision II. ÚS 307/2014-45 of December 18, 2014 by the Slovak Constitutional Court ${ }^{40}$ dealt with the repercussions of the advent of social media on the interpretation of TV broadcasting rules. The case derived from proceedings against a decision by the Slovak media regulator which found that a TV broadcaster had breached domestic rules for objective and impartial news reporting. According to the Constitutional Court, relevant rules should henceforth be interpreted with the characteristics of the evolving media ecosystem taken into account, in particular the broad variety of operators available and the emergence of social media. ${ }^{41}$ Against this backdrop, the Constitutional Court held that impartiality standards amounted to a restriction on TV broadcasters' freedom of expression and that such a restriction was unlawful because it could not be justified by any of the permissible grounds for restrictions on free speech laid down in the Slovak Constitution and the ECHR. ${ }^{42}$ Particularly regarding restrictions on free speech, the Constitutional Court asserted that the state's margin of appreciation went hand in hand with supervision by the ECtHR and the Constitutional Court itself, and that supervision covered both the legislation concerned and its application, mainly through courts. Several ECtHR rulings where the Strasbourg Court had expanded on the features of European supervision on the state's margin of appreciation were mentioned in this context, namely Handyside $v$. the United Kingdom, ${ }^{43}$ Sunday Times v. the United Kingdom (No 1), ${ }^{44}$ Tele 1 Privatfernseh v. Austria ${ }^{45}$ and Movement Raëlien Suisse v. Switzerland. ${ }^{46}$

Notably, in discussing free speech and the obligations deriving from it for state authorities, the Constitutional Court identified a positive obligation for the state to secure pluralist sources of information in society. To strengthen its reasoning on this point, the Constitutional Court referred to the ECtHR's decision in Çetin and Others $v$. Turkey, ${ }^{47}$ concerning an administrative ban on the distribution of a daily newspaper in Turkey that had been imposed without proper reasoning and without the ban being subjected to judicial scrutiny. The Constitutional Court recalled that the ECtHR had rejected the argument of the Turkish government, according to which the applicants had not suffered interference with their free speech as journalists because they were involved in the publication of various newspapers in Turkey and had thus been able to impart ideas and information through other means. ${ }^{48}$ Citizens - the ECtHR had affirmed — should be allowed to receive a variety of information and views so they could choose those upon which to shape their opinions. ${ }^{49}$

The decision of the Slovak Constitutional Court is also one of the rare decisions within our sample where foreign case law was referenced. Alongside a number of ECtHR rulings ${ }^{50}$ mentioned as part of the domestic court's reasoning on the importance of freedom of expression in a

\footnotetext{
${ }^{40}$ Ústavného súdu Slovenskej republiky [Constitutional Court of the Slovak Republic], Case II. ÚS 307/2014-45, Dec. 18, 2014, https://tinyurl.com/y8yot6zd.

${ }^{41} I d$. at para. 59.

${ }^{42} I d$. at para. 62 (discussing namely the protection of the rights and freedoms of others, national security, public order, health and morals).

${ }^{43}$ Handyside v. The United Kingdom, App. No. 5493/72, para. 49 (Dec. 7, 1976), http://hudoc.echr.coe.int/eng?i=00157499.

${ }^{44}$ Sunday Times v. the United Kingdom (No. 1), App. No. 6538/74, para. 59 (Apr. 26, 1979), http://hudoc.echr.coe.int/eng? $\mathrm{i}=001-57584$.

${ }^{45}$ Tele 1 Privatfernseh v. Austria, App. No. 32240/96, para. 34 (Sep. 21, 2000), http://hudoc.echr.coe.int/eng?i=001-58803.

${ }^{46}$ Movement Raëlien Suisse v. Switzerland, App. No. 16354/06, paras. 59-60 (July 13, 2012), http://hudoc.echr.coe.int/eng? $\mathrm{i}=001-112165$.

${ }^{47}$ Çetin and Others v. Turkey, App. Nos. 40153/98, 40160/98 (Feb. 13, 2003), http://hudoc.echr.coe.int/eng?i=001-60940.

${ }^{48} \mathrm{Id}$. at para. 64 .

${ }^{49} \mathrm{Id}$.

${ }^{50}$ See Handyside, App. No. 5493/72; Observer and Guardian v. The United Kingdom, App. No. 13585/88 (Nov. 26, 1991), http://hudoc.echr.coe.int/eng?i=001-57705; Oberschlick v. Austria, App. No. 11662/85 (May 23, 1991), http://hudoc.echr.coe. int/eng?i=001-57716; Nilsen and Johnsen v. Norway, App. No. 23118/93 (Nov. 25, 1999), http://hudoc.echr.coe.int/eng?i= 001-58364; Rádio Twist v. Slovak Republic, App. No. 62202/00 (Dec. 19, 2006), http://hudoc.echr.coe.int/eng?i=001-78603; Axel Springer v. Germany, App. No. 39954/08 (Feb. 7, 2012), http://hudoc.echr.coe.int/eng?i=001-109034; Centro Europa 7 SRL and Di Stefano v. Italy, App. No. $38433 / 09$ (June 7, 2012), http://hudoc.echr.coe.int/eng?i=001-111399; Ringier Axel Springer Slovakia v. Slovak Republic (No. 2), App. No. 21666/09 (Jan. 7, 2014), http://hudoc.echr.coe.int/eng?i=001-139899.
} 
democratic society ${ }^{51}$ the Constitutional Court referred to several rulings of the German Federal Constitutional Court, the Czech Constitutional Court, and the Slovenian Constitutional Court. ${ }^{52}$ General statements contained in these rulings were cited to underline the significance of free speech as one of the essential foundations of democracy and to underscore the role of the media for the provision of information on matters of public interest, the facilitation of public debate, and the formation of public opinion. ${ }^{53}$ In holding that free speech is not absolute and that restrictions can be allowed, the Slovak Constitutional Court also made reference to the seminal ruling of the Supreme Court of the United States of America in Schenck v. United States. ${ }^{54}$ There, the Supreme Court established that restrictions on freedom of expression are allowed when the expression creates a "clear and present" danger to a legitimate public interest. ${ }^{55}$

Decision Up-540/11 of February 13, 2014 by the Slovenian Constitutional Court ${ }^{56}$ contains references to ECtHR and foreign case law as well. Here, the dispute revolved around whether or not a violation of Article 37 of the Slovenian Constitution had occurred. Article 37 of the Slovenian Constitution guarantees the privacy of correspondence and other means of communication. ${ }^{57}$ It requires that any restriction be prescribed by law, be based on a court order, be limited in duration, and be necessary for the institution or course of criminal proceedings or for reasons of national security.

The facts of the case are as follows: After obtaining data on the complainant's dynamic Internet Protocol (IP) address from the Swiss police, which had monitored the users of a file-sharing network involving child pornography, law enforcement authorities in Slovenia obtained data regarding the user to whom the above-mentioned IP address had been assigned by the relevant Internet service provider (ISP) without a court order. The complainant had been subsequently found guilty of the criminal offence of possession and distribution of pornographic material. The Constitutional Court did not accept the argument advanced by the complainant that the evidence for his conviction had been gathered in breach of the right to privacy of communication. According to the Constitutional Court, the complainant had no legitimate expectation of privacy: He had not hidden the IP address through which he had accessed the Internet in any way, and he had consciously exposed himself to the public since access to the file-sharing network in question was not restricted..$^{58}$ Consequently, the data concerning his identity as the user of the dynamic IP address at issue did not come within the ambit of protection of Article 37 of the Slovenian Constitution. ${ }^{59}$

Article 37 of the Slovenian Constitution. on the right to privacy of communication was mentioned in conjunction with Article $8 \mathrm{ECHR}$ on the right to respect for private and family life, together with the ECtHR's ruling in K.U. v. Finland. ${ }^{60}$ This ECtHR decision was about the publication of an advertisement of a sexual nature on an Internet dating site in the name of a minor. The offender had posted the ad online pretending to be a twelve-year-old boy, who had become aware of the ad when contacted with an offer to meet. Domestic legislation in Finland on the protection of confidentiality in electronic communications at the time made provision for the

\footnotetext{
${ }^{51}$ Ústavného súdu Slovenskej republiky, Case II. ÚS 307/2014-45 at para. 34.

${ }^{52}$ See Federal Constitutional Court of Germany, Cases 1 BvR 400/51, January 15, 1958; 1 BvR 131/96, March 24, 1998; 2 BvR 2219/01, December 15, 2004; 1 BvR 2020/04, December 10, 2010; Constitutional Court of the Czech Republic, Cases I. ÚS 823/ 11, March 6, 2012; II. ÚS 357/96, December 10, 1997; IV. ÚS 23/05, July 17, 2007; Constitutional Court of the Republic of Slovenia, Case Up-2940/07, February 5, 2009.

${ }^{53}$ Ústavného súdu Slovenskej republiky, Case II. ÚS 307/2014-45 at paras. 35-37, 40.

${ }^{54}$ See Schenck v. United States, 249 U.S. 47 (1919).

${ }^{55} I d$. at 49.

${ }^{56}$ Ustavno sodišče Republike Slovenije [Constitutional Court of the Republic of Slovenia], Case Up-540/11, ECLI:SI: USRS:2014:Up.540.11, Feb. 13, 2014, https://www.us-rs.si/decisions/?lang=en\&id=111578.

${ }^{57}$ See Art. 37, Constitution of the Republic of Slovenia, https://www.us-rs.si/media/constitution.pdf.

${ }^{58}$ Ustavno sodišče Republike Slovenije, Case Up-540/11 at paras. 14, 18.

${ }^{59} \mathrm{Id}$. at para. 18.

${ }^{60}$ K.U. v. Finland, App. No. 2872/02 (Dec. 2, 2008), http://hudoc.echr.coe.int/eng?i=001-89964.
} 
disclosure of telecommunications identification data only in relation to certain offences. On this basis, the Finnish courts had refused to oblige the ISP to divulge the identity of the user of the dynamic IP address at issue, so that the applicant could bring charges, with reference to the requirement for the protection of secrecy. The Constitutional Court recalled that by prioritizing the confidentiality of communications against the minor's physical and mental integrity, the Finnish authorities had been found to have violated Article 8 ECHR. ${ }^{61}$ For the ECtHR, effective protection under Article 8 ECHR entailed a positive obligation on the state for effective deterrence against such serious acts against fundamental values and essential aspects of private life, in the form of efficient criminal law provisions enabling the identification and prosecution of the perpetrator. $^{62}$

Whereas reference to K.U. v. Finland appears to have been made mostly for informative reasons as part of background information on Article 8 ECHR and its interpretation by the ECtHR, the Constitutional Court also integrated in its reasoning the ECtHR's rulings in Malone v. the United Kingdom ${ }^{63}$ and P.G. and J.H. v. the United Kingdom. ${ }^{64}$ According to these rulings, Article 8 ECHR should be construed as protecting not only the content of communication but also the circumstances and facts related to the communication. ${ }^{65}$ In a similar vein, the Constitutional Court observed that protection under Article 37 of the Slovenian Constitution should be construed as covering not only the content of communication but also traffic data, that is, "any data processed for the transmission of communications in an electronic communications network or for the billing thereof." ${ }^{\prime 6}$ For the Constitutional Court, IP addresses were traffic data and, thus, the question was whether or not the complainant legitimately expected privacy regarding his dynamic IP address.

Considering that there was no interference with the complainant's right to privacy of communication, as the complainant had knowingly exposed himself to the public, the Constitutional Court also referred to a decision of the Austrian Constitutional Court. ${ }^{67}$ It stated that, on the basis of constitutional requirements similar to those of Article 37 of the Slovenian Constitution, the Austrian Constitutional Court had found that when police authorities obtain the content of a message either from a communication that is available to the public or from a communication that is closed to the public, with disclosure taking place by one of the participants in the communication, protection cannot be granted on grounds of the secrecy of communications. ${ }^{68}$

Reference to foreign case law and the ECtHR decisions in Malone v. the United Kingdom and P.G. and J.H. v. the United Kingdom ${ }^{69}$ showed consistency in the interpretation of domestic constitutional provisions with foreign and ECHR provisions on the secrecy of communications. Particularly with regards to the interaction of Article 37 of the Slovenian Constitution with Article 8 of the ECtHR, the Constitutional Court also engaged in comparative reasoning: it declared that domestic constitutional provisions ensured a higher level of protection. ${ }^{70}$ While the requirement set forth in Article 37 of the Slovenian Constitution for a court order to be issued for any kind of interference with the right to privacy of communication seems to have played a

\footnotetext{
${ }^{61}$ Ustavno sodišče Republike Slovenije, Case Up-540/11 at para. 10.

${ }^{62}$ K.U., App. No. 2872/02 at paras. 43, 46, 49.

${ }^{63}$ Malone v. The United Kingdom, App. No. 8691/79 (Aug. 2, 1984), http://hudoc.echr.coe.int/eng?i=001-57533.

${ }^{64}$ P.G. and J.H v. the United Kingdom, App. No. 44787/98 (Sept. 25, 2001), http://hudoc.echr.coe.int/eng?i=001-59665.

${ }^{65}$ Ustavno sodišče Republike Slovenije, Case Up-540/11 at para. 10.

${ }^{66} \mathrm{Id}$. at para. 13 .

${ }^{67}$ Id. at paras. $18,24$.

${ }^{68}$ In the case reviewed by the Austrian Constitutional Court, after a criminal complaint had been filed with the police by a chatroom participant that had suspicions about a criminal offence being committed by another chatroom participant, the police obtained data on the IP address used for the communication in the chatroom by that other participant, and then data such as the name, surname, and address of the user of the IP address without a court order.

${ }^{69}$ See Malone, App. No. 8691/79 at para. 84; P.G. and J.H., App. No. $44787 / 98$ at para. 42.

${ }^{70}$ Ustavno sodišče Republike Slovenije, Case Up-540/11 at para. 11.
} 
role here, the higher level of protection supposedly offered by the Slovenian Constitution did not secure a decision in line with Article 8 ECHR - as shown in the ECtHR's decision in Benedik $v$. Slovenia. $^{71}$

Called upon to rule on this case, the ECtHR found that the fact that the applicant had not hidden his dynamic IP address was not decisive in the assessment of whether or not he had a legitimate expectation of privacy. ${ }^{72}$ What was significant was whether he reasonably expected privacy in relation to his identity. ${ }^{73}$ The ECtHR found that he did. The applicant had never disclosed his identity in relation to his online activity ${ }^{74}$ his dynamic IP address-even if visible to other network users - could not be traced to the specific computer without the ISP verifying the relevant data, ${ }^{75}$ and statutory regulation in Article 37 of the Slovenian Constitution guaranteed that any interference with the right to privacy of communication would rest on a court order. ${ }^{76}$

Thus, considering that the request of the police to the ISP and the use made of the subscriber information leading to the applicant's identification amounted to interference with the applicant's right to respect for private life, ${ }^{77}$ the ECtHR examined whether the interference was in conformity with the requirements of Article 8(2) ECHR. It concluded that it was not "in accordance with the law" and that a violation of Article 8 ECHR had occurred. ${ }^{78}$ The ECtHR found that the provisions of the Criminal Procedure Act that had been relied upon by the police were not sufficiently clear for the type of data disclosure request in question. ${ }^{79}$ Also, they did not form part of a coherent legal framework regarding the level of protection granted to the right to respect for private life, ${ }^{80}$ they did not offer adequate protection against arbitrary interference, ${ }^{81}$ and they were not complemented by rules that specified the conditions for the retention of the data obtained and safeguards against abuse by state officials with respect to access to and transfer of such data. ${ }^{82}$

Case Up-540/11 of the Slovenian Constitutional Court ${ }^{83}$ is important because the privacy perspective that it endorsed is intrinsically connected with questions concerning the protection of secrecy of communication online. The issue is not only linked to anonymous use of social media and blogs; it also relates to the qualification of communication on social media-as public or private-and the differences that may exist depending on whether communication takes place on personal social media profiles-where a reasonable expectation of privacy might exist under conditions_-social media groups, or open social media pages.

\section{E. Supreme Courts: Judicial Interaction with Domestic Constitutional Courts and European Supranational Courts}

The majority of the supreme court cases under examination engaged in internal horizontal judicial dialogue with references to the jurisprudence of domestic constitutional courts. Most of the cases reviewed also included an external vertical judicial dialogue dimension with references to decisions of the CJEU and the ECtHR. Mention of constitutional court rulings was for the most part

\footnotetext{
${ }^{71}$ Benedik v. Slovenia, App. No. 62357/14 (Apr. 24, 2018), http://hudoc.echr.coe.int/eng?i=001-182455.

${ }^{72} I d$. at para. 116 .

${ }^{73} \mathrm{Id}$.

${ }^{74} I d$. at para. 117.

${ }^{75} I d$.

${ }^{76} I d$. at para. 118.

${ }^{77} I d$. at para. 120.

${ }^{78} \mathrm{Id}$. at paras. $133-134$.

${ }^{79} \mathrm{Id}$. at para. 127.

${ }^{80} I d$.

${ }^{81} I d$. at para. 124.

${ }^{82} I d$. at para. 130.

${ }^{83}$ Ustavno sodišče Republike Slovenije [Constitutional Court of the Republic of Slovenia], Case Up-540/11, Feb. 13, 2014, ECLI:SI:USRS:2014:Up.540.11, https://www.us-rs.si/decisions/?lang=en\&id=111578.
} 
made to show consistency with the findings of the domestic constitutional court. Use of the jurisprudence of the CJEU and the ECtHR was similarly made to support their findings.

\section{Internal Horizontal Judicial Dialogue}

Decision II.IPS.307/2014 of September 17, 2015 by the Supreme Court of Slovenia focused on whether or not a blog post in an online news portal with reference to a known writer's sexual life was in breach of her right to privacy, which is protected under Article 35 of the Slovenian Constitution, and had therefore to be removed. ${ }^{84}$ Lower courts in Slovenia had found the plaintiff's claims to be unjustified, taking the view that the blog post in question merely summarized the content of the plaintiff s books, as promoted by the plaintiff. ${ }^{85}$ The Supreme Court did not adhere to this. The issue at hand, as was clarified, was to strike an appropriate balance between the right to privacy and the right to free speech, enshrined in Article 39 of the Slovenian Constitution, and assess the proportionality of the interference with the former for the purposes of protecting the latter. ${ }^{86}$ The plaintiff had indeed disclosed information on her private life herself. However, the blog post also contained statements that were not intended to "inform the public" but rather sought to "personally disqualify the plaintiff."

In assessing the interference with the plaintiff's right to privacy, the Supreme Court referred to certain rulings of the Slovenian Constitutional Court as part of legal background analysis on the right to respect for private life and its collision with other rights. ${ }^{88}$ According to judgment Up-444/09 of April 12, 2012 by the Slovenian Constitutional Court, for instance, the less intimate the area of an individual's private life was, the less protection should be enjoyed by the right to privacy, when in conflict with other rights and interests. ${ }^{89}$ However, the specificities of the individual whose privacy rights were encroached upon should also be taken into account. As regards public persons in particular, it was permissible to disclose- without consent - any aspects related to the "character, actions and thoughts" of public persons "in relation to their public engagement." ${ }^{90}$ By contrast, any aspects about their intimate life should not be published without consent. ${ }^{91}$ In addition, the degree of protection afforded to privacy should be considered to be lower when individuals "exposed themselves" to the public. ${ }^{92}$ Taking note of the reasoning of the Slovenian Constitutional Court, including in judgment Up-345/01 of February 5, 2004, which had underlined the importance of freedom of expression for the search for truth, public scrutiny and opinion formation, ${ }^{93}$ the Supreme Court held that the contested blog post in part reflected the promotion of the plaintiff s books and in part discredited the plaintiff and was therefore illegal. ${ }^{94}$

Reference to constitutional court rulings appears to have been made within our sample mostly to document the reasoning of the deciding judge on the interpretation of applicable constitutional

\footnotetext{
${ }^{84}$ Vrhovno sodišče [Supreme Court], Case II.IPS.307.2014, ECLI:SI:VSRS:2015:II.IPS.307.2014, Sept. 17, 2015, http://www. sodnapraksa.si/?q=ips\%20307/2014\&database\%5BSOVS\%5D=SOVS\&_submit=i\%C5\%A1\%C4\%8Di\&rowsPerPage=20\& page $=0$ \&id $=2015081111389070$.

${ }^{85} I$ d. at paras. $14,22$.

${ }^{86} I$ d. at para. 15 .

${ }^{87} \mathrm{Id}$. at para. 25.

${ }^{88} \mathrm{Id}$. at paras. 20, 22, 25.

${ }^{89} I d$. at para. 20.

${ }^{90} \mathrm{Id}$.

${ }^{91} I d$.

${ }^{92}$ Id. at para. 22. In judgment UI-172/94 of 9 November 1994, the Slovenian Constitutional Court had in fact ruled that when an individual participated in a social event, he or she assumed the risk that his or her conduct might be subject to discussion and comment.

${ }^{93} \mathrm{Id}$. at para. 25 .

${ }^{94} I d$. at paras. $22-23,27$.
} 
provisions, covering fundamental rights provisions. ${ }^{95}$ In one of the cases under review, reference to constitutional court rulings was also made to demonstrate consistency with the jurisprudence of the CJEU, emphasizing endorsement of the CJEU's pronouncements by the domestic constitutional court. Thus, in decision 51143/2014 of May 12, 2014 ${ }^{96}$ - discussed in more detail in part E3 in connection to judicial dialogue with the CJEU-the Italian Supreme Court gave thorough consideration to decision 174/2010 of May 13, 2010 by the Italian Constitutional Court. This had addressed focal points of the CJEU's decision in Marra,${ }^{97}$ a preliminary ruling focused on the interpretation of the EU legal framework governing the system of immunity and privileges for the members of the European Parliament. The Supreme Court pointed in particular to the fact that the Constitutional Court had integrated the CJEU's findings in its reasoning. ${ }^{98}$

Judicial dialogue with domestic constitutional courts in the cases reviewed generally reflects the willingness of the deciding judge to follow and adhere to the verdicts of the constitutional court. However, there are also instances within our sample where the deciding judge refused to align judicial reasoning to that of the constitutional court. Decision 5Sž/11/2015 of March 28, 2017 of the Slovak Supreme Court is a useful example of this. ${ }^{99}$ This case originated in a dispute concerning the Slovak media regulator's decision that found a TV broadcaster to have violated domestic rules on labelling requirements for minors' protection. ${ }^{100}$ In reaction to one of the pleas of the TV broadcaster, the Supreme Court referred to decision II. ÚS 307/2014-45 of the Slovak Constitutional Court. ${ }^{101}$ The TV broadcaster had challenged the proportionality of the media regulator's decision and to substantiate its argument, it had cited the ruling of the Slovak Constitutional Court where the mitigating effects of social media on the interpretation of TV broadcasting rules had been acknowledged. ${ }^{102}$ The Supreme Court took the Constitutional Court's decision into account ${ }^{103}$ but refrained from adopting a similar stance in support of a less cumbersome interpretation of existing labelling requirements for TV broadcasting. According to the Supreme Court, labelling requirements amounted to a legitimate restriction on TV broadcasters' free speech for the purposes of protecting the moral development of minors, which was necessary and proportional to the objective pursued. ${ }^{104}$

\section{External Vertical Judicial Dialogue: Dialogue with the ECtHR}

Turning to judicial dialogue with supranational courts, the abundance of ECtHR rulings on digital media, freedom of expression and the latter's balancing with the right to respect for private life has allowed national judges to choose those ECtHR decisions that conveniently serve to underline particular points in domestic judicial reasoning. To illustrate, in decision II.IPS.307/2014, ${ }^{105}$ the Slovenian Supreme Court referred to Article 39 of the Slovenian Constitution, together with

\footnotetext{
${ }^{95}$ For example, in decision 31022/2015 of the Italian Supreme Court (see infra-Part. 5.2 on judicial dialogue with the ECtHR), the Supreme Court referred to the jurisprudence of the Italian Constitutional Court in relation to Article 21 of the Italian Constitution on freedom of expression and the conditions under which the seizure of the press can be exceptionally permitted.

${ }^{96}$ Corte Suprema di Cassazione (Cass.) [Supreme Court of Cassation], Case 14 May 2014, 51143 (It.).

${ }^{97}$ ECJ, Joined Cases C-200/07 \& 201/07, Alfonso Luigi Marra v. Eduardo De Gregorio and Antonio Clemente, ECR I-7929, Judgment of 21 Oct. 2008.

${ }^{98}$ Namely that absolute immunity for the votes cast and opinions expressed in the performance of parliamentary duties should be established on the basis of EU law alone and that exclusive competence for verifying the conditions of absolute immunity rested with national courts. See Cass. 51143, supra note 96, at paras. $2.3 \& 2.5$.

${ }^{99}$ Najvyšši súd [Supreme Court], Case 5Sž/11/2015 (Mar. 28, 2017), https://www.nsud.sk/data/att/50320.pdf (Slo.).

${ }^{100} I d$. at paras $1-2$.

${ }^{101}$ See supra Part D.

${ }^{102}$ Particularly as regards impartiality requirements.

${ }^{103}$ Najvyšši súd, at para. 43.

${ }^{104} \mathrm{Id}$.

${ }^{105}$ See supra Part E(1).
} 
Article $10 \mathrm{ECHR},{ }^{106}$ as part of legal analysis on freedom of expression and the blog post in question. Mention of the ECtHR rulings in Lingens v. Austria ${ }^{107}$ and Thorgeir Thorgierson v. Iceland ${ }^{108}$ was made in this context to stress that besides verifiable data or facts, free speech protection also includes opinions, criticism and even speculation. ${ }^{109}$ In Lingens $v$. Austria, one of the seminal ECtHR rulings on freedom of expression, the ECtHR affirmed that free speech is "applicable not only to 'information' or 'ideas' that are favorably received or regarded as inoffensive or as a matter of indifference, but also to those that offend, shock or disturb."110

The Slovenian Supreme Court also referred to Jacubowski v. Germany, ${ }^{111}$ emphasizing that the protection of free speech should not be affected by whether or not the content of speech was in the public interest. ${ }^{112}$ In Jacubowski v. Germany, the ECtHR had indeed declared that the fact that free speech may be "exercised other than in the discussion of matters of public interest does not deprive it of the protection of Article 10 ECHR." 113 Reference to Observer and Guardian v. the United Kingdom ${ }^{114}$ sought in turn to exemplify the point that free speech is not absolute and that it can be restricted. ${ }^{115}$ Relevant restrictive grounds, however, including the protection of the honor and rights of others, should be interpreted narrowly and the necessity for any of the restrictions upheld convincingly established. ${ }^{116}$ Pursuant to the ECtHR case law, the Supreme Court went on, in the case of violations of one's honor or reputation, a distinction should be drawn between facts and opinions or value judgments. ${ }^{117}$ This distinction has been part and parcel of the ECtHR's jurisprudence in defamation cases, with the ECtHR clarifying that contrary to the existence of facts that can be demonstrated, the truth of value judgments is not susceptible to proof. Still, the Supreme Court cautioned, the ECtHR had made clear that, in the case of value judgments, the proportionality of interference with free speech should be assessed in light of whether there was a sufficient factual basis to support the statement made. Failing this, a value judgment should be considered excessive. ${ }^{118}$ In the case at hand, the Supreme Court concluded that the disputed blog went far beyond the notion of opinion or criticism; it was an attack on the plaintiff. ${ }^{119}$

ECtHR case law has similarly assisted the deciding judge in several cases adjudicated by the Italian Supreme Court. These examined the qualification of social media and blogs vis-à-vis the press, in disputes concerning the legality of injunctions for the seizure, as a precautionary measure, of allegedly defamatory content posted online. Decision 31022/2015 of January 29, 2015 in particular focused on an injunction for the seizure of a webpage of an online newspaper ${ }^{120}$ and decision 11895/2013 of October 30, 2013 on an injunction for the seizure of a blog. ${ }^{121}$ In the

\footnotetext{
${ }^{106}$ Vrhovno sodišče, at para. 18.

${ }^{107}$ Lingens v. Austria, App. No. 9815/82 (July 8, 1986), http://hudoc.echr.coe.int/eng?i=001-57523.

${ }^{108}$ Thorgeir Thorgeirson v. Iceland, App. No. 13778/88 (June 25, 1992), http://hudoc.echr.coe.int/eng?i=001-57795.

${ }^{109}$ Vrhovno sodišče, at para. 19.

${ }^{110}$ Lingens v. Austria, at para. 41.

${ }^{111}$ Jacubowski v. Germany, App. No. 15088/89 (June 23, 1994), http://hudoc.echr.coe.int/eng?i=001-57879.

${ }^{112}$ Vrhovno sodišče, at para. 19.

${ }^{113}$ See Jakubowski v. Germany at para. 25. The case had originated in a dispute over an injunction restraining a journalist from distributing to fellow professionals a circular that accompanied press cuttings concerning his former employer and endorsing their critical statements.

${ }^{114}$ See Observer and Guardian v. the United Kingdom, supra note 50.

${ }^{115}$ Vrhovno sodišče, at para. 19.

${ }^{116} I$. .

${ }^{117} I d$. at para. 26.

${ }^{118} I d$.

${ }^{119} I d$. at paras 23 and 27.

${ }^{120}$ Corte Suprema di Cassazione (Cass.) [Supreme Court of Cassation], Case 17 July 2015, 31022, (It.)., https://www. giurisprudenzapenale.com/wp-content/uploads/2015/08/cass-pen-sez-un-2015-31022.pdf.

${ }^{121}$ Corte Suprema di Cassazione (Cass.) [Supreme Court of Cassation], Case 30 October 2013, 11895, (It.), http://www. penale.it/page.asp?IDPag $=1151$.
} 
former, the Italian Supreme Court explained that the online press could benefit from the constitutional prohibition of seizure of the press on condition that it had the same structure and characteristics as the printed press. ${ }^{122}$ Social media and blogs did not come within the concept of the press and therefore could not benefit from relevant constitutional guarantees. ${ }^{123}$

Judicial reasoning in decision 31022/2015 developed with consideration given to the ECtHR jurisprudence on freedom of expression and its importance for the press. The Supreme Court underlined key points emerging from the ECtHR's case law, namely that the press plays a vital role as a public watchdog, that the public enjoys a right to receive information and ideas on matters of public interest - this goes hand in hand with a duty incumbent on the press to impart information and ideas on matters of public interest ${ }^{124}$ _ and that protection of free speech extends to opinions that are not favorably received. ${ }^{125}$ Particular mention was made in the ECtHR rulings of Fressoz and Roire v. France, Observer and Guardian v. the United Kingdom and Vogt v. Germany. ${ }^{126}$ Whereas the first two cases were related to the press, ${ }^{127}$ Vogt v. Germany focused on the dismissal of a teacher from the civil service due to her political activity, which was found to be a violation of Article 10 ECHR. ${ }^{128}$

Specifically, as regards the comparability of the printed press with the online press, the Italian Supreme Court referred to Wegrzynowski and Smolczewsky v. Poland. ${ }^{129}$ This ECtHR decision had derived from Polish courts' refusal to order a newspaper to remove from its Internet archive an article that damaged the applicant's reputation. The ECtHR had ruled in particular that online press "archives" fell within the ambit of protection of Article 10 ECHR, even if the risk of harm posed by content and communications on the Internet to the exercise of fundamental rights was higher than that posed by the printed press. ${ }^{130}$ Notably, Wegrzynowski and Smolczewsky v. Poland was also mentioned in decision 11895/2013 of the Italian Supreme Court. ${ }^{131}$ Here, the Supreme Court likewise found that blogs could not come within the scope of the constitutional provisions against seizure targeting the press. However, any precautionary measure of seizure should be adopted with respect for the principle of proportionality, given the importance of blogs for free speech. ${ }^{132}$ To stress its point, the Supreme Court underlined that freedom of expression was enshrined in Article 10 ECHR and Article 11 CFR besides Article 21 of the Italian Constitution and drew attention to Wegrzynowski and Smolczewsky v. Poland as one of the latest ECtHR rulings on the subject matter of interest. ${ }^{133}$

The national judge has occasionally referred to the ECtHR's judicial practice, without identifying any specific cases. For example, in decision 159/2015 of June 19, 2015 by the Supreme Court of Bulgaria, ${ }^{134}$ mention of Article $10 \mathrm{ECHR}$ was combined with a general reference to the

\footnotetext{
${ }^{122}$ Cass., Case 31022 , at paras. $17,19-20,22-23$.

${ }^{123} \mathrm{Id}$. at para. 18 .

${ }^{124}$ See Observer and Guardian v. the United Kingdom at para. 59(b).

${ }^{125}$ Cass., Case 31022 , at para. 14 .

${ }^{126}$ Fressoz and Roire v. France, App. No. $29183 / 95$ (Jan. 21, 1999), http://hudoc.echr.coe.int/eng?i=001-58906; Vogt v. Germany, App. No. 17851/91 (Sep. 26, 1995), http://hudoc.echr.coe.int/eng?i=001-57949; Observer and Guardian v. the United Kingdom.

${ }^{127}$ Observer and Guardian v. the United Kingdom and Fressoz and Roire v. France concerned respectively the conviction of journalists for publishing unlawfully obtained tax information and the grant of interlocutory injunctions restraining the press from publication.

${ }^{128}$ Vogt v. Germany, at paras 54-61.

${ }^{129}$ Węgrzynowski and Smolczewsky v. Poland, App. No. 33846/07 (16 July 2013), http://hudoc.echr.coe.int/eng?i=001122905 (mentioned at Cass. 31022, at para. 22).

${ }^{130} I d$. at para. 58 .

${ }^{131}$ Cass., Case 11895/2013, at para. 5.1.

${ }^{132} I d$. at paras 5.1 and 5.2 .

${ }^{133} \mathrm{Id}$. at para. 5.2 .

${ }^{134}$ Върховен касационен съд [Supreme Court of Cassation], June 19, 2015, Case 159/2015, http://www.ex-lege.info/?id= 417358 (Bulg.).
} 
jurisprudence of the ECtHR on freedom of expression. The case focused on the qualification of the crime of insult in an online environment, in connection to the conviction of a journalist for having made social media statements that attacked the honor and dignity of a politician. The Bulgarian Supreme Court acknowledged that in accordance with the ECtHR's case law, restrictions on free speech should be interpreted narrowly and that the limits of acceptable criticism vis-à-vis public figures in particular were wider. In fact, there should be no restriction on free speech in cases of criticism concerning the professional and public activity of a public figure. In this specific case, however, the journalistic statements made affected the intimate sphere of the politician in a degrading manner and were not necessary or acceptable in discussion of her professional development and political career.

\section{External Vertical Judicial Dialogue: Dialogue with the CJEU}

Decision 51143/2014 of May 12, 2014 by the Italian Supreme Court is one of the few cases in our sample where an extremely detailed account of CJEU case law was incorporated in the reasoning of the domestic court. ${ }^{135}$ Consideration was given in particular to the CJEU jurisprudence in cases Marra and Patriciello, ${ }^{136}$ where the CJEU had the opportunity to interpret the EU legal framework on the immunity and privileges of members of the European Parliament. The Italian case stemmed from a dispute over the publication of allegedly defamatory statements by a member of the European Parliament against an Italian judge and her husband, a lawyer, on a blog. In defamation proceedings against the member of the European Parliament, the parliamentarian made a request to the European Parliament seeking defense of his immunity in accordance with the procedure set forth at the time in the Rules of Procedure of the European Parliament. ${ }^{137} \mathrm{He}$ argued that the blog post in question was an expression of political activity aimed to inform on deficiencies in the Italian justice system. ${ }^{138}$ The request for defense of immunity was recommended for adoption and the deciding judge granted immunity, with the case eventually reaching the Italian Supreme Court.

Pursuant to Article 8 of Protocol (no. 7) on the privileges and immunities of the European Union (PPI), "members of the European Parliament shall not be subject to any form of inquiry, detention or legal proceedings in respect of opinions expressed or votes cast by them in the performance of their duties." 139 According to the CJEU, such immunity seeks to protect the freedom of expression and independence of members of the European Parliament and constitutes an absolute immunity, barring any judicial proceedings with respect to an opinion expressed or a vote cast in the exercise of parliamentary duties. ${ }^{140}$ The Italian Supreme Court clarified that in accordance with the Marra ruling, ${ }^{141}$ establishing whether the conditions for immunity are met lay with the exclusive

\footnotetext{
${ }^{135}$ See Cass., Case 51143/2014.

${ }^{136}$ ECJ, Joined Cases C-200/07 \& 201/07, Marra, supra note 97; Case C-163/10, Patriciello, ECR I-7565, Judgment of 6 September 2011..

${ }^{137}$ See European Parliament Rules of Procedure, 2005 O.J. (L 44) 1. Rule 6(3) provides that "Any request addressed to the President by a Member or a former Member to defend privileges and immunities shall be announced in Parliament and referred to the committee responsible." Pursuant to Rule 7(6), the committee responsible should then state whether the circumstances amounted to a restriction and invite the authority concerned to draw the necessary conclusions. According to Rule $7(7)$, this could offer a reasoned opinion about the competence of the authority in question and about the admissibility of the request.

${ }^{138}$ Cass., Case $51143 / 2014$, at para. 2.

${ }^{139}$ See Protocol No. 7 on the Privileges and Immunities of the European Union, art. 8, 2012 O.J. (C 326) 266. On the regime of immunities of members of the European Parliament, see European Parliament, The Immunity of Members of the European Parlament: In-Depth Analysis for the JURI COMmitTeE (2014), https://www.europarl.europa.eu/ RegData/etudes/IDAN/2014/509981/IPOL_IDA(2014)509981_EN.pdf.

${ }^{140}$ Marra at para. 27.

${ }^{141} I d$. at para. 33.
} 
jurisdiction of national courts. ${ }^{142}$ The national judge was not obliged to refer the question to the European Parliament as the latter had no powers, pursuant to the PPI, to determine whether the conditions for immunity were fulfilled. ${ }^{143}$ In line with the duty of sincere cooperation between the European institutions and national authorities, however, national judicial authorities should cooperate with the European Parliament to avoid any conflict in the interpretation and application of the provisions of the PPI. ${ }^{144}$

The Italian Supreme Court continued to identify key findings of the CJEU's decision in Patriciello. ${ }^{145}$ The emphasis was placed on the fact that Article 8 PPI-intended to apply to statements made within the precincts of the European Parliament ${ }^{146}$ - could also cover statements made elsewhere. These should, however, amount, in their character and content, to an opinion expressed "in the performance of parliamentary duties." ${ }^{477}$ For the CJEU, the Supreme Court observed, ${ }^{148}$ the benefit of immunity presupposed a "direct" and "obvious" connection between the opinion expressed and parliamentary duties. ${ }^{149}$ On the basis of such considerations, the Supreme Court reached the conclusion that a rather abstract judicial evaluation of the blog posts concerned had been performed without verification of the CJEU's requirement for a direct and obvious link between the posts and the performance of parliamentary functions. ${ }^{150}$

In decision 31022/2015, ${ }^{151}$ alongside mention of the ECtHR's ruling in Wegrzynowski and Smolczewsky v. Poland, the Italian Supreme Court also referred-as part of supranational case law on the comparability of the online press to the printed press-to the CJEU's decision in eDate advertising and Others. ${ }^{152}$ In this case, the CJEU had offered guidance on the courts that have jurisdiction in case of an infringement of personality rights on the Internet. ${ }^{153}$ In particular, it had interpreted Article 5(3) of Council Regulation (EC) No 44/2001 of December 22, 2000 on jurisdiction and the recognition and enforcement of judgments in civil and commercial matters. ${ }^{154}$ This allows proceedings to be brought in the courts of "the place where the harmful event occurred or may occur," by way of derogation from the principle of jurisdiction of the courts of the place of domicile of the defendant. ${ }^{155}$

Drawing on an earlier case, Shevill and Others, ${ }^{156}$ the CJEU recalled in eDate advertising and Others that a victim of defamation by a newspaper that is distributed in several EU Member States can bring an action for damages against the publisher of the newspaper either before the courts of the Member State of the place of establishment of the publisher or before the courts of each Member State in which the publication has been distributed and where the victim claims to have suffered injury. ${ }^{157}$ Whereas the former enjoy jurisdiction to award damages for all the harm

\footnotetext{
${ }^{142}$ Cass., Case 51143/2014, at para. 2.4 (part: consideration in law).

${ }^{143}$ Marra, at para. 32 .

${ }^{144} I d$. at paras 42-43. In particular, should an action be brought against a member of the European Parliament, the national court should stay proceedings if informed that a procedure for defense of the privileges and immunities of that member had been initiated ( $i d$. at para. 43). Once the national court had established, however, that the conditions for immunity were met, immunity could not be waived by the European Parliament and the national court should dismiss the action brought against the parliamentarian concerned (id. at para. 44).

${ }^{145}$ Cass., Case 51143/2014, at para. 2.6 (part: consideration in law).

${ }^{146}$ Patriciello at para. 29.

${ }^{147} I d$. at para. 30 .

${ }^{148}$ Cass., Case 51143/2014, at para. 2.6 (part: consideration in law).

${ }^{149}$ Patriciello at paras. 33, 35.

${ }^{150}$ Cass., Case 51143/2014, at para. 2.7 (part: consideration in law).

${ }^{151}$ See supra Part E(2).

${ }^{152}$ ECJ, Joined Cases C-509/09 \& C-161/10, eDate Advertising and Others, ECLI:EU:C:2011:192, Judgment of 15 Oct. 2011.

${ }^{153} \mathrm{Id}$. at paras $29,37$.

${ }^{154}$ Council Regulation (EC) No. 44/2001 of 22 Dec. 2000, on jurisdiction and the recognition and enforcement of judgments in civil and commercial matters, 2001 O.J. (L 12) 1.

${ }^{155}$ Id. at Art. 2(1).

${ }^{156}$ Shevill v. Presse Alliance SA, Case C-68/93, ECR I-415, Judgment of 7 March 1995.

${ }^{157}$ eDate Advertising and Others, at para. 42.
} 
caused, the latter have jurisdiction to rule solely on the harm caused in the Member State of the court seized. ${ }^{158}$ In Shevill and Others, the CJEU had explained that the diverse possibilities available for bringing an action for damages stemmed from the fact that "the place where the harmful event occurred," pursuant to what was then Article 5(3) of the Convention on Jurisdiction and the Enforcement of Judgments in Civil and Commercial Matters, ${ }^{159}$ covered both the place where the damage occurred and the place of the event giving rise to the damage. The place where the damage occurred should be understood as the place where the event giving rise to the damage produced its harmful effects upon the victim: The place of distribution of the publication in question. ${ }^{160}$ As for the place of the event giving rise to the damage - this was the place of establishment of the publisher ${ }^{161}$ — which should generally coincide with the head of jurisdiction: The courts of the Member State of the defendant's domicile. ${ }^{162}$

In eDate advertising and Others, the CJEU adapted its interpretation of the special jurisdiction rule laid down in Article 5(3) of Regulation No 44/2001 to the specificities of the online environment. ${ }^{163}$ The main rationale behind such adaptation was that an online publication should be distinguished from the distribution of the printed press, in that it was intended, in principle, to render the content ubiquitous. ${ }^{164}$ This reduced the usefulness, within the context of the Internet, of the criterion relating to the occurrence of damage and therefore of the criterion of the place of distribution of content. ${ }^{165}$ Moreover, it also aggravated the nature of the harm that could be suffered precisely because the injurious content was available on a world-wide basis. ${ }^{166}$ In light of such considerations, the CJEU took the position that besides the courts of the Member State where the publisher was established, an action for liability with respect to all the damage caused could also be brought before the courts of the Member State where the center of interests of the person concerned ${ }^{167}$ was based. ${ }^{168}$ In addition, in accordance with the criterion of the place where the damage occurred, an action could also be brought, in line with Shevill and Others, before the courts of each Member State where the impugned content was or had been accessible. In this case, however, the courts enjoyed jurisdiction only with respect to the damage caused in the territory of the Member State of the court seized. ${ }^{169}$

The Italian Supreme Court did not enter the specificities of the CJEU's ruling. It refrained from offering an account of the CJEU's decision and did not expand on the precise input in the CJEU's reasoning in the case. Decision 31022/2015 thus stands in marked contrast with decision 51143/ 2014 and the latter's meticulous analysis of the CJEU's jurisprudence.

\footnotetext{
${ }^{158} \mathrm{Id}$.

${ }^{159}$ See 1968 Brussels Convention on Jurisdiction and the Enforcement of Judgments in Civil and Commercial Matters, Publications OfFice of The European Union (Jan. 26, 1998), https://op.europa.eu/en/publication-detail/-/publication/ 0e63083c-47ab-4e17-9f94-c319950e98dc/.

${ }^{160}$ Shevill and Others at paras $28,29$.

${ }^{161} I d$. at para. 24.

${ }^{162} I d$. at para. 26.

${ }^{163} I d$. at para. 52.

${ }^{164}$ eDate Advertising and Others, at para. 45.

${ }^{165} \mathrm{Id}$. at paras $46-47$.

${ }^{166} I d$. at para. 47.

${ }^{167}$ See id. at para. 49 . The CJEU held that the center of interests corresponds in general to ones' habitual residence. However, other factors, such as the pursuit of a professional activity, may establish the existence of a particularly close link with a state other than the state of habitual residence.

${ }^{168} \mathrm{Id}$. at para. 48 . The center-of-interests criterion was considered to be especially apposite, supportive of the sound administration of justice, given that the influence of the online publication on the personality rights of the concerned individual can be best assessed by the court of the place where the alleged victim had his/her center of interests.

${ }^{169} I d$. at para. 51.
} 


\section{F. Conclusion}

Dialogue between judges has been intrinsically connected to debates about consistency and quality in judicial interpretation. The increase in the number of rulings on social media, blogs, chat rooms and so on over the past few years has brought to center stage the important role that courts play in a legal area that is still evolving. In the sample of social media cases analyzed, the assumption has been that judges would be favorably disposed to judicial dialogue as a means to cope with rapid technological change and complex legal problems, besides seeking to address disputes that raise fundamental rights questions in a coherent manner. The rate of judicial dialogue within our sample was still quite low.

A clear preference has been noted towards the use of constitutional court rulings and the ECtHR's jurisprudence as a point of reference when engaging in judicial dialogue. Constitutional court rulings have been mostly referred to in connection with the interpretation of constitutional provisions, especially those on fundamental rights. Mention of constitutional court cases was mainly used as a supporting argument, bolstering judicial reasoning by showing consistency with the interpretations of the domestic constitutional court. However, there are also instances where the deciding judge acknowledged the reasoning of the constitutional court without adhering to it. ${ }^{170}$

Reference to European court decisions has relied on a broad range of rulings enabling particular points - especially in the ECtHR's reasoning - to be stressed. Occasionally, the national judge referred to the ECtHR's jurisprudential practice without singling out any specific cases. ${ }^{171}$ Reference to European supranational case law has generally shown that domestic judicial reasoning unfolds in line with the jurisprudence of the CJEU and the ECtHR. In none of the cases under examination did the national judge express disapproval of or disagree with the findings of the European courts.

Turning to foreign case law, this was used least within our sample. Certainly, resort to foreign court decisions requires careful consideration of the comparability of the foreign legal context with the national one. In fact, it is more likely that national courts will follow and pay attention to the jurisprudence of foreign courts that belong to a legal system similar to the national legal system. In the limited instances within our sample where the national court engaged with foreign jurisprudence, this was to validate domestic judicial reasoning by bringing attention to the fact that similar conclusions were also reached elsewhere.

Overall, judicial dialogue through references to case law in the cases reviewed displays varying degrees of detail. Whereas some cases were merely mentioned without any substantive analysis, others were used to stress particular points in judicial reasoning. There are also cases within our sample where the national court gave a thorough account of the case law referred to, explaining in detail how this fed domestic judicial assessment. Mention in particular of the CJEU's jurisprudence may have lagged behind the ECtHR's case law in terms of the frequency of references, but in some cases it has been extremely detailed, making a valuable contribution to and substantiating the reasoning of the deciding judge.

Cases such as decision 51143/2014 of the Italian Supreme Court, ${ }^{172}$ for instance, where domestic judicial reasoning drew directly on the findings of the CJEU in Marra and Patriciello, confirm the crucial input that engagement with CJEU case law may offer the national judge. It is true that the dispute in question was visibly associated with the application of EU rules-namely, the system of immunity and privileges of the members of the European Parliament-and that both Marra and Patriciello were preliminary rulings of the CJEU on the interpretation of these rules - what is more triggered by Italian courts, ${ }^{173}$ which might explain such accurate understanding of

\footnotetext{
${ }^{170}$ See Najvyšši súd, supra Part E(1).

${ }^{171}$ Sее Върховен касационен съд, supra Part E(2).

${ }^{172}$ See supra Part E(3).

${ }^{173}$ The Italian Supreme Court and the District Court of Isernia respectively.
} 
the CJEU's reasoning by the Italian Supreme Court. Decision 51143/2014 also shows that judicial dialogue through references to CJEU case law may occur in a context that verges on compliance; the CJEU's preliminary rulings_-besides being binding on the referring court-also function as legal precedents for other courts in the EU Member States. However, even in less constraining contexts of judicial interaction within our sample, national courts have benefited from the judicial reasoning of peers. The use of ECtHR case law in particular has markedly served to enrich and solidify domestic judicial reasoning with national courts carefully selecting the ECtHR rulings according to the arguments to be supported. 